\title{
Effects of Underwater Lipus on the Morphohistology of the CF-1 Mice Growth Plate in Late Lactation Stage
}

\author{
Efectos del Ultrasonido Subacuático Sobre la Morfohistología de la \\ Placa de Crecimiento de Ratones CF-1 en Etapa de Lactancia Tardía
}

\author{
Ricardo Henríquez'; Tuillang Yuing ${ }^{1}$; Gonzalo Pallauta ${ }^{3}$; Roberto Muñoz ${ }^{4}$; \\ Adolfo Saavedra²; Paulina Nuñez ${ }^{2} \&$ Mario Valenzuela ${ }^{2}$
}

\begin{abstract}
henRíQUeZ, R.; YUING, T.; PALlaUTA, G.; MUÑoZ, R.; SAAVEDRA, A.; NUÑEZ, P. \& VALENZUELA, M. Effects of underwater lipus on the morphohistology of the CF-1 mice growth plate in late lactation stage. Int. J. Morphol., 35(4):1351-1358, 2017.

SUMMARY: Ultrasound is one of the most used tools in physiotherapy, its LIPUS modality allows to treat musculoskeletal injuries, but like the conventional ultrasound it is contraindicated its application in areas close to growth cartilage by a possible closure of this one. In the literature there is no conclusive evidence of this contraindication, so the objective of the present study is to evaluate the effects of doses equivalent to underwater LIPUS on the histomorphometry of the proximal tibial epiphysis growth plate in an animal model. LIPUS was applied in underwater mode in the right pelvic limb to 8 mice in $p 15$ for 4 days, 2 times a day. On completion of 8 sessions the histology of the stimulated limb growth plate was sacrificed and the histology. When evaluating the histomorphometry of the plaque, a significant increase in the thickness and area of the proliferative zone stimulated with LIPUS $(p=0.048)$ was observed. In the hypertrophic area were observed no significant differences in thickness or areas, but in the hypertrophic area there were significant changes in the histological organization, observing a significant increase of the entire columns in the stimulated plaque ( $p=0.04)$. LIPUS in underwater modality modifies the histomorphometry of the proximal epiphyseal PC of the tibia of rodents in the late postnatal stage, promoting proliferation and columnar organization in the proliferative and hypertrophic zone, respectively.
\end{abstract}

KEY WORDS: Low-intensity pulsed ultrasound; CF-1 mice; Late lactation; Growth Plate.

\section{INTRODUCTION}

Ultrasound (US) is a type of mechanical wave characterized by a frequency higher than $20 \mathrm{kHz}$ (Cameron, 2009). For decades the US has been used as a tool for physiotherapy that promotes tissue repair in musculoskeletal injuries. (Padilla et al., 2014). The modification of the parameters of the US wave allows to focus the treatment to different tissues, different depths and generate varied effects, covering a wide spectrum of therapeutic objectives norms according to the FDA (Cameron).

One of the US modalities presenting the most clinical evidence is the low-intensity pulsed ultrasound (LIPUS), Which corresponds to a pulsating application characterized by the use of final intensities less than $0.1 \mathrm{~W} / \mathrm{cm}^{2}$ (Cameron). The athermic effects of LIPUS have proven to be beneficial in the repair of unbound fractures (Cameron; Padilla et al.).
As for the contraindications for the use of the US, in a review conducted by Batavia (2004), it was determined that the application of US in areas close to the growth plate (PC) is the second most frequently reported contraindication in the specialized literature (Batavia). This contraindication has its origin in a publication by DeForest et al. (1953), who observed the closure of the PC after the application of high doses of US. Based on this background, it is proposed as a contraindication to apply therapeutic US in pediatric patients in areas close to the PC, since it could cause a premature closure of the plaque or alterations in the chondrocyte maturation (Cameron).

The PC is a characteristic structure of the endochondral ossification processes, it is composed of highly organized cartilaginous tissue, it is located between the epiphysis and the diaphysis of the long bones and whose main function is the modulation of the longitudinal growth

\footnotetext{
${ }^{1}$ Escuela de Kinesiología, Facultad de Salud, Universidad Santo Tomas, Chile.

${ }^{2}$ Facultad de Ciencias, Pontificia Universidad Católica de Valparaíso, Chile

${ }^{3}$ CESFAM Santa Cecilia, Departamento de Salud Coquimbo, Coquimbo, Chile.

${ }^{4}$ Programa Más Adultos Mayores Autovalentes, CESFAM Cirujano Videla, Corporación Municipal de Desarrollo Social Iquique, Iquique, Chile.
} 
of the bone (van der Eerden et al., 2003). The PC is divided into three zones, each with distinctive morphological characteristics (Mackie et al., 2008), From epiphysis to diaphysis, we will find:

The reserve zone (ZR) is composed of progenitor chondrocytes. These cells are crucial for the orientation of the chondrocyte columns of the contiguous zones, and therefore, fundamental in the orientation of bone growth, probably secreting a PC orientation factor (Mackie et al.). These chondrocytes upon receiving various stimuli are able to begin to proliferate, giving rise to the proliferative zone (van der Eerden et al.).

In the proliferative zone (ZP), the chondrocytes adopt a flattened appearance, begin to divide, are organized in columns and initiate the synthesis of substantial amounts of extracellular matrix of collagen (MEC) (van der Eerden et al.).

In the hypertrophic zone $(\mathrm{ZH})$, chondrocytes have a rounded appearance due to cytoplasmic hypertrophy, accompanied by a marked intracellular increase in calcium concentration, and an increase in the synthesis and secretion of X-type collagen, in addition to other proteins Of the MEC (van der Eerden et al.).

In the proximity of the diaphysis the hypertrophic chondrocytes $(\mathrm{CH})$ enter into apoptosis, left an ECM scaffold for the bone tissue in formation (van der Eerden et al.). After the death of $\mathrm{HC}$, there will be empty lagoons, spaces that will later be occupied and invaded by blood vessels and osteoprogenitor cells, osteoclasts, osteoblasts and bone marrow cells (Mackie et al.).

The process of differentiation and passage from the progenitor chondrocyte to the $\mathrm{CH}$ is regulated by internal factors and factors external to the PC.

Within the external factors it is possible to emphasize the mechanical loads. The bony tissue exposed to mechanical loads responds with diverse adaptations both elastic and plastic, described by two laws; The Law of Wolf, which finally expresses the activity of bone formation and resorption (Villemure \& Stokes, 2009), And the HueterVolkmann Act, which refers to mechanical waves (expressed in external stresses) exerted on the PC modulating the length and bone geometry of a developing bone (Villemure \& Stokes).

There is evidence that US application of bone tissue in fractures accelerates metabolism and promotes cell differentiation (Padilla et al.). Since the fracture repair process replicates many ossification phases of bone growth, it is assumed that the acceleration effects in the consolidation of traditional US fractures and LIPUS doses are extrapolated to the ossification process (Cameron). Based on this background, Korstjens et al. (2008) in vitro cultures of chondrocytes obtained from patients with osteoarthritis (in vitro) after the application of classical LIPUS for 6 days, observed an increase in the rate of proliferation. Nolte $e t$ al. (2001) performed a morphohistological analysis on in vitro cultures of metatarsals after the application of LIPUS for 6 days, observing changes in the rate of bone growth expressed in an increase in the length of the diaphysial ossification center. It was hypothesized that this result could be explained by the activation of the PI3K / Akt pathway as the trigger for proliferation of chondrocytes mediated by LIPUS (Takeuchi et al., 2008).

In in vivo studies, Oyanarte et al. (2009) when applying LIPUS for 26 days in mandibular condyles of male rats, found an increase in ECM secretion in $\mathrm{ZH}$, increased chondrocyte hypertrophy in $\mathrm{ZH}$ and alterations in the cellular order of the treated group. After the application of LIPUS to the temporomandibular joint of rabbits for 4 weeks, El-Bialy et al. (2003) found an increase in chondrocyte hypertrophy of the chondrogenic layer, increased endochondral ossification and a marked increase in Metabolic activity in the group treated with LIPUS. On the other hand, Lyon et al. (2003) and Barreto et al. (2011) found alterations in thickness and number of chondrocytes of the layers after US application with high intensities (greater than 1 [W / cm2]), Attributing these results to the thermal effects of US, since they did not find changes with doses with athermic effects, as they are the ones inferior to $0.5\left[\mathrm{~W} / \mathrm{cm}^{2}\right]$.

In summary, from this background we could deduce that the in vivo evidence would not consistently describe morphological alterations of the PC product of the application of LIPUS and that the alterations observed could be related to thermal effects of the highest intensity of US.

In clinical practice, air is not an adequate medium for the propagation of the US, the main means of propagation must be a coupling material between the target tissue and the US head, some of the most commonly used, are gel or water (underwater US) (Cameron). Underwater US is a method which involves steeping the tissue to be treated and the head US. Although there is very little research regarding this modality, the evidence maintains that it facilitates the coupling of irregular surfaces with a lower heat transfer, reducing the thermal effects (Poliachik et al., 2014) And increasing the area of effective irradiation of the head, improving the safety of the therapeutic application (Cameron). 
There is evidence that in in vitro models LIPUS increases the proliferation of chondrocytes, but these effects are not clearly replicated in the PC morphology of in vivo models. There is only evidence that the morphological alterations would be related to thermal effects of high intensity US. In this context, one of the modalities of US application that diminish the thermal effects is the underwater application, the effects of LIPUS applications in underwater mode on the morphology and histology of the PC. For this reason the objective of the present study is to evaluate the effects of doses equivalent to underwater LIPUS on the histomorphometry of the growth plate of the proximal tibia epiphysis in an animal model.

\section{MATERIAL AND METHOD}

Samples and US Application Protocol. Eight male mice of the 15-day-old CF-1 strain (p15) were housed in plexiglass cages under controlled laboratory conditions with reverse light-dark cycle at $20 \pm 2{ }^{\circ} \mathrm{C}$, With water and food ad libitum. All care and procedures were developed in accordance with the Canadian Manual of Care and Use of Experimental Animals (Olfert et al., 1993).

At 15 days the mice were treated twice daily for 4 consecutive days with an underwater LIPUS application protocol, which consisted of sedation with chloroform and immersion of the limbs in water at a temperature of $26 \pm 1^{\circ}$ C. The US was applied in an underwater mode in a pool of Plexiglass with Enraf Sonopuls $491^{\circledR}$ equipment aimed at the right pelvic limb that was held, while the lower left limb was subject in the same conditions as its contralateral, but isolated from the waves Ultrasonic by a double wall with air interface. The left pelvic limb was used as a control sample.

The parameters used were for SATA similar to LIPUS for bone repair, with $1[\mathrm{MHz}]$ being the pulsatile base frequency with a SATA of $0.03\left[\mathrm{~W} / \mathrm{cm}^{2}\right]$ for 3 minutes. It is important to note that these parameters do not produce significant increases in the local temperature (Poliachik et $a l$.). The US team was calibrated and the distance from the near field underwater at the same temperature of the procedure was evaluated by technicians of the responsible brand. According to the report of the technicians the near field was described up to a distance of $110 \mathrm{~mm}$, taking into account the low dispersion and high homogeneity of the wave in the near field, it was decided to place the limbs at $80 \mathrm{~mm}$ of the transducer.

Once the 8 sessions of LIPUS were fulfilled, a day for the sacrifice was waited in order to allow the effect of the US. At day p20 the mice were sacrificed by intraperitoneal injections of thiopental. It is important to emphasize that all the handling, care and sacrifice of animals was in accordance with the Canadian Guide on Care and Use of Experimental Animals (Olfert et al.).

Preparation, photographing and analysis of histological samples. The histological samples were prepared in the Laboratory of Histological Techniques of the Pontificia Universidad Católica de Valparaíso, Chile.

The pups were fixed immediately postmortem in Bouin for 72 hours, and were dissected at the hip level, however, for the analysis only the tibia was used. After extraction, the samples were decalcified in $10 \% \mathrm{w} / \mathrm{v}$ ethylidiaminetetracetic acid (EDTA, pH 7.4) for 3 days, and then dehydrated in a battery of alcohols (70 \% to $100 \%)$ to be included in cubes Paraffin (Paraplast $\left.{ }^{\circledR}\right)$.

At the end of these processes, coronal sections were extracted from each tibia (5- $7 \mu \mathrm{m}$ thick). The cuts of greater bone length were selected and rehydrated in a battery of alcohols at descending concentrations. Hematoxylin - eosin sections were stained to finally mount the sample on a slide.

Only histological images of the proximal tibial PC were used. The photomicrographs were taken with a Hearter BA$410^{\circledast}$ light microscope and a Canon ${ }^{\circledR}$ EOS 5D Mark digital camera, under controlled lighting conditions and at a $5 \mathrm{x}$ magnification. The images were imported in digital format and measurements were performed with the Image Pro Plus ${ }^{\circledR}$ program.

Morphometric analysis of the PC. In order to delimit the PC areas, the criteria described by Miralles-Flores \& Delgado-Baeza (1992). Specifically, ZP was defined as the zone extending from the first flattened chondrocyte proximal to the epiphysis, to the first $\mathrm{CH}$ proximal to the diaphysis. The $\mathrm{ZH}$ was delimited from the first $\mathrm{CH}$ proximal to the epiphysis and the last transverse septum proximal to the diaphysis, or to the last rounded $\mathrm{CH}$.

The thickness and area of ZP and ZH were evaluated. To measure the thickness of the $\mathrm{CP}$ zones, the criteria described by Snow et al. (2007) were used. The thickness of each zone was determined from the arithmetic average of five measurements per zone, performed parallel to the axial axis of the bone, between the limits defined by zones and taken at equidistant intervals throughout the thickness of the corresponding zone. The thickness of the PC was estimated as the sum of the mean lengths of ZP and ZH (Snow et al.). The area of each zone was evaluated using the Image Pro Plus $^{\circledR}$ area polygon tool. 
The ZR was not evaluated because its magnitude is greatly diminished by the presence of secondary ossification points at this stage of growth.

Histological analysis of the PC. The columns of the $\mathrm{ZH}$ and $\mathrm{ZP}$ were analyzed, where the number of total columns (CT) of the $\mathrm{ZP}$ and $\mathrm{ZH}$ were observed; and the number of cells in the $\mathrm{ZH}(\mathrm{nZH})$ per column. When estimating the $\mathrm{CT}$ of the $\mathrm{ZH}$, two types of columns were also considered: complete columns (CC), whose length is equal to the thickness of the corresponding zone, and incomplete columns (IC), where the length of the column is smaller than the thickness of the corresponding area (Miralles-Flores \& Delgado-Baeza). Subsequently all the data were tabulated in the program Microsoft Excel 2010 for statistical analysis.

Statistical Methods. The data were analyzed by means of descriptive statistics, expressing the mean, standard deviation, standard error and coefficients of variation of each parameter. The distribution was also evaluated by the Shapiro-Wilk test for the treated samples and control samples.

Inferential statistics were evaluated using Student's $\mathrm{T}$ for non-parametric data (Mann-Whitney Test U), using a $\mathrm{p} \leq 0.05$ as a significant value.

\section{RESULTS}

The weight of the mice was evaluated every day, from day 1 of treatment (day 15 postnatal) (Fig. 1), there were no significant changes in the weight of the pups during the days of treatment.

As for total PC thickness (Fig. 2A), measured as the sum of $\mathrm{ZP}$ and $\mathrm{ZH}$, no significant differences were found between Control $(256.7 \pm 36 \mu \mathrm{m})$ and LIPUS $(295.3 \pm 42$ $\mu \mathrm{m}) \mathrm{p}=0.242$.

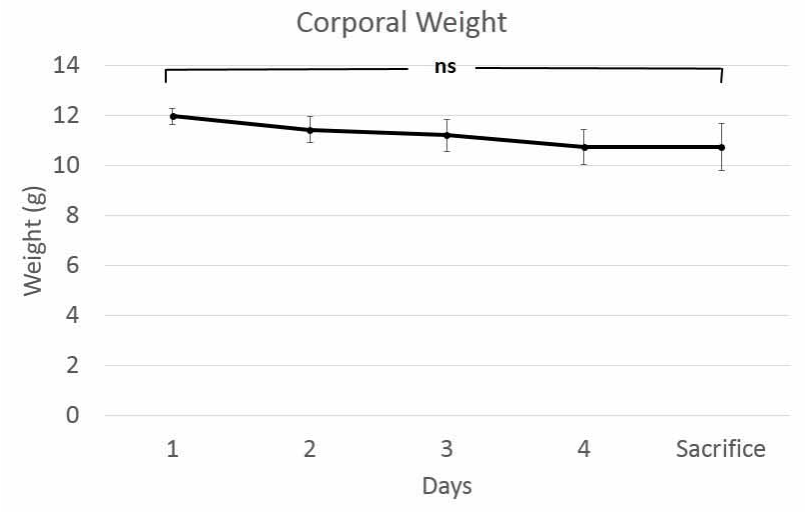

Fig. 1. Body weight gains in the day of treatments; Day 1 of treatment is the 15 postnatal day; $n=8 ; n s=p>0,05$.
A

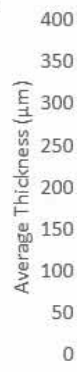

C

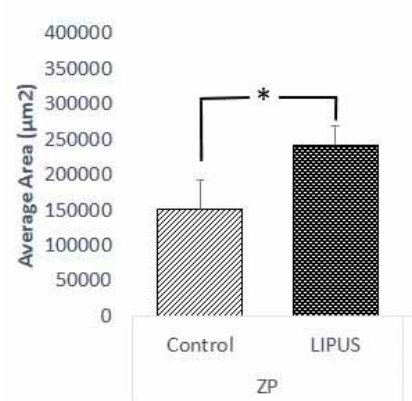

B

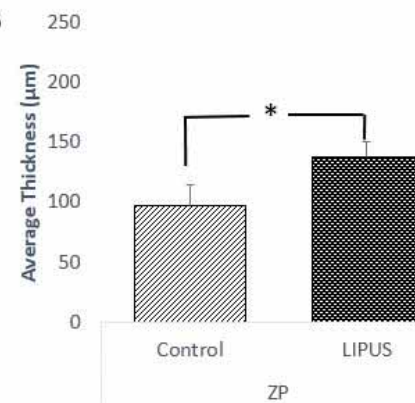

D

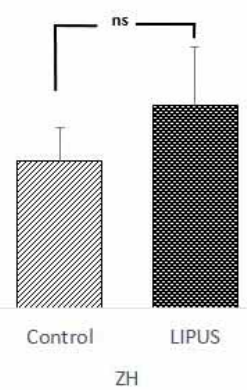

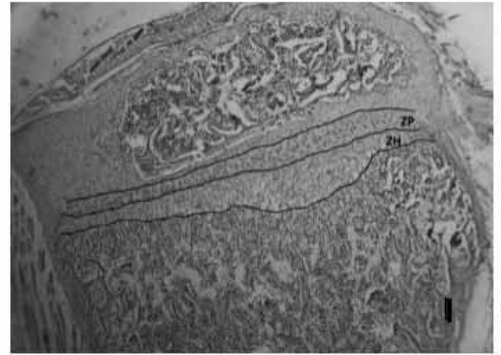

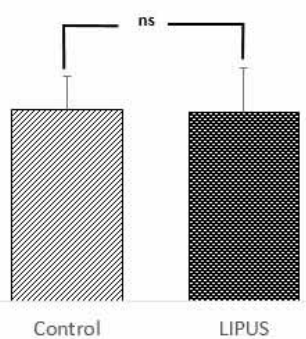

$\mathrm{ZH}$

$E$

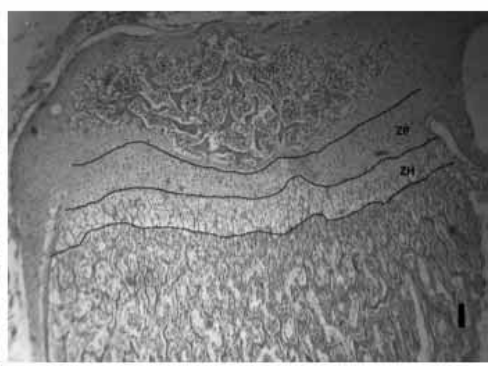

Fig. 2. Morphometric effects of LIPUS application on total PC thickness (A); Effect of LIPUS on the thickness of the proliferative zone $(\mathrm{ZP})$ and the hypertrophic zone (ZH) (B); Effect of LIPUS on the area of the proliferative zone (ZP) and the hypertrophic zone (ZH) $(\mathrm{C})$; Representative photograph of the control growth plate $(P C)(D)$; Representative photograph of the LIPUS growth plate $(P C)(E) . n s=p>0,05$; $*=\mathrm{p}<0,05$; Bars: $100 \mu \mathrm{m}$ 
Analyzing the thicknesses of the layers separately, a significant increase in the ZP thickness of the LIPUS samples $(137.71 \pm 12.78 \mu \mathrm{m})$ was observed in comparison to the Control samples $(97.11 \pm 17.49 \mu \mathrm{m}, \mathrm{p}=0.048)$, without significant changes in $\mathrm{ZH}$ (control 159.6 $\pm 27.97 \mu \mathrm{m}$, LIPUS $157.6 \pm 37.52 \mu \mathrm{m}, \mathrm{p}=0.34$ ) (Figs. 2B, 2D \& 2E).

Similar results were observed when analyzing the areas of each of the zones, the area of ZP was significantly higher in the group exposed to LIPUScompared to the control samples (Control 151394.86 $\pm 41082.29 \mu \mathrm{m}^{2}$, LIPUS 241221.56 (Control: 208424 $\pm 47202 \mu \mathrm{m}^{2}$, LIPUS 286108 $\left.\pm 83227 \mu \mathrm{m}^{2}, \mathrm{p}=0.34\right)($ Figs. 2C, 2D \& 2E).

When evaluating the histology of the areas described, no significant differences were observed in the number of total columns in the evaluated zones (Fig. 3A) (ZP: control $114.5 \pm 30.74$, LIPUS $146.5 \pm 30.09, \mathrm{p}=0.5),(\mathrm{ZH}$ : control $140.3 \pm 29.460$, LIPUS $133.8 \pm 41.850, \mathrm{p}=0.44)$.

As for the type of columns observed, there was a significant increase in complete columns (Figs. 3B, 3D and $3 \mathrm{E})$ in the samples exposed to LIPUS $(14 \pm 4,813)$, compared to the control samples $(5 \pm 2,380), \mathrm{p}=0.048$.

A
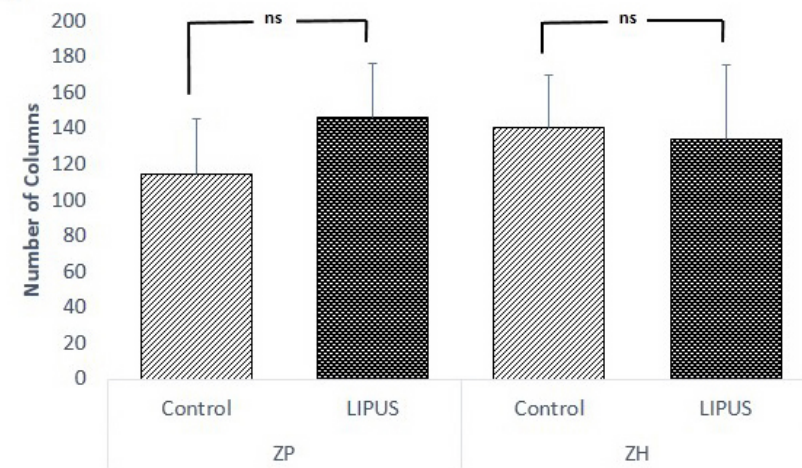

C

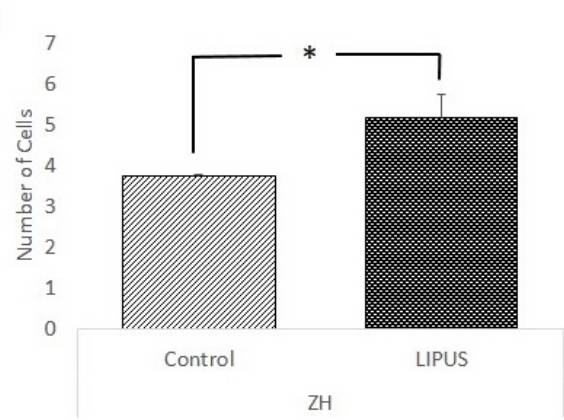

In $\mathrm{ZH}$ the average cell number of each column was evaluated by observing a significant increase of cells per column in the samples exposed to LIPUS $(5.16 \pm 0.582$ cells / col) relative to the control samples $(3.75 \pm 0.023$ cells / Col) (Figs. 3C, 3D and 3E), p = 0.04.

\section{DISCUSSION}

The aim of the present study is to evaluate the effects of dose equivalent to underwater LIPUS on the histomorphometric development of $\mathrm{CP}$ in male $\mathrm{CF}-1$ mice in post-lactation phase p20.

The application of US with doses similar to LIPUS in underwater mode at a distance of $80 \mathrm{~mm}$ seeks to reduce the thermal effects, with a uniform and constant beam of ultrasound. To achieve this, as mentioned in the methodology, the equipment was calibrated to empirically determine the distance range of the near field. Poliachik et al. showed that with intensities lower than $100 \mathrm{~mW} / \mathrm{cm}^{2}$, in underwater mode the thermal effects are minimized. With respect to beam uniformity, Shaw \& Hodnett (2008) argues theoretically that

B
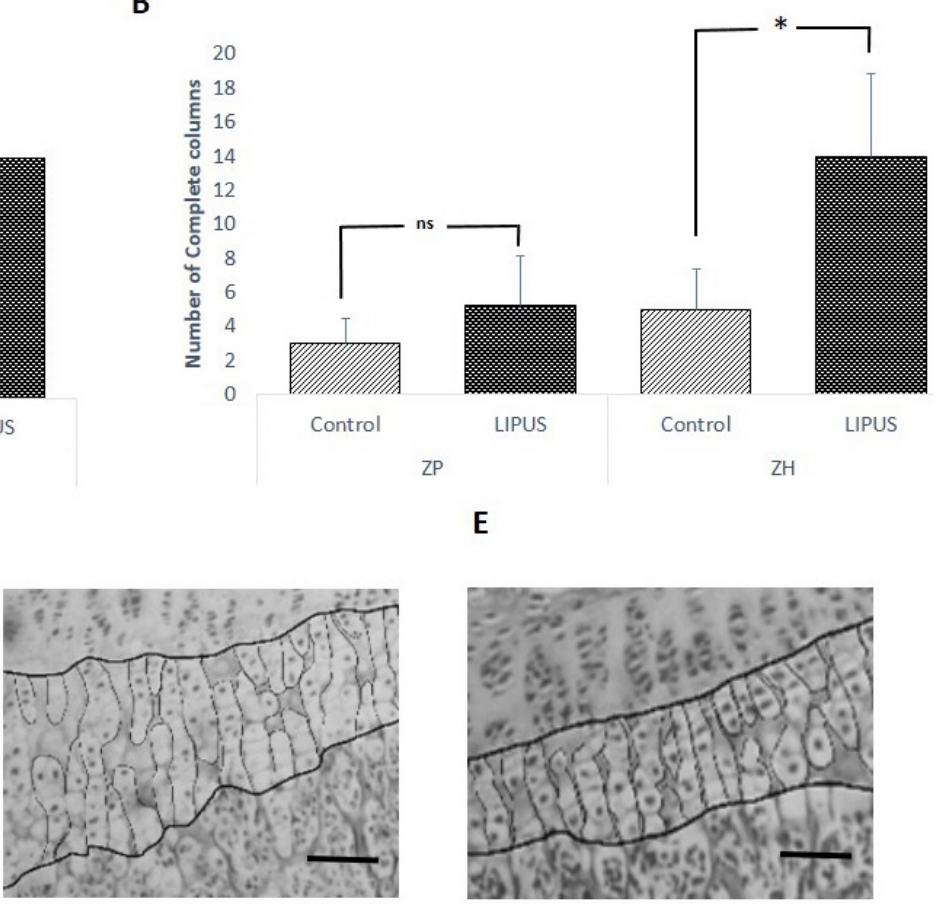

Fig. 3. Histological effects of LIPUS application on number of total columns in the proliferative zone (ZP) and the hypertrophic zone (ZH) (A); Effect of LIPUS on the complete columns of the proliferative zone (ZP) and the hypertrophic zone (ZH) (B); Effect of LIPUS on the number of cells per column in the hypertrophic zone $(\mathrm{ZH})(\mathrm{C})$; Representative photograph of the control growth plate (PC)(D); Representative photograph of the LIPUS growth plate(PC) (E). ns $=p>0,05 ; *=p<0,05$; Bars: $100 \mu m$ 
for a head of $5 \mathrm{~cm}^{2}$ the boundary between the near-distant fields is $100 \mathrm{~mm}$. Therefore, according to the literature and the empirical measurement performed during the calibration of the equipment, the distance of $80 \mathrm{~mm}$ is located in the near field, in which the peak of intensities (area of beam uniformity) is prevented and The attenuation of the wave, and the thermal effects are minimized.

When analyzing the weight of rodents during LIPUS treatment, no significant changes in body weight were observed. Bustamante et al. (2013) describe that in the early postnatal stage of CF-1 strain rodents, significant increases in body weight can be observed. In the case of the present study this significant increase was not observed, showing that the treatment of underwater LIPUS in sessions of 2 times a day for 4 days, has systemic effects on the development of the rodent. In the present study the same rodent was used to obtain the stimulated sample and the control sample, thanks to this strategy we can expect that the systemic effects of the underwater treatment affected the control samples and the stimulated samples in the same way. Therefore, the differences observed in the histomorphology of CP can be directly attributed to exposure to the ultrasonic beam and should not be attributed to the treatment modality and its systemic effects.

It is important to note that this is the first study to analyze the morphometric and histological changes on the PC after the application of US with doses similar to LIPUS in underwater mode, on tibiae of mice in the late lactation period.

At the morphometric level, the LIPUS samples showed a significant increase in the thickness and area of the ZP. Similar results were found by Wiltink et al. (1994) who, when evaluating the effects of LIPUS on endochondral ossification observed an increase in $\mathrm{ZP}$, with no change in $\mathrm{ZH}$, in metatarsal cultures of mice of 16 and 17 days of age lifetime. Likewise, Takeuchi et al. and Zhang et al. (2003) observed an increase in chondrocyte proliferation following LIPUS application in samples obtained from phalangeal metatarsal articulation of 6-month-old pigs and sternum of embryos of 16-day chicken respectively.

The morphometric changes in the ZP could be explained by the activation of the mechanoreceptor Integrina / Pax-Fax, located in the chondrocytes, which through mechanical stimulation generates activation of the pathway PI3k / Akt, inhibiting the phosphorylation of B-Catenin, which on accumulation migrate to the nucleus promoting cell proliferation and MEC secretion genes (Takeuchi et al.). This phenomenon is strongly related to the intensity of application of the US, being low intensities, as in LIPUS the most efficient in its activation (Zhang et al.). Another possible mechanism involved in the increase of chondrocyte proliferation is that LIPUS through its mechanical waves can generate extracellular fluid flows, redistributing the nutrients inside the PC allowing a better use of these for cell proliferation (Zauhar et al., 2006).

In the case of the $\mathrm{ZH}$, no significant differences were observed in the area and thickness of this zone, which could be explained because the pathways stimulated by LIPUS mainly induce the proliferation of chondrocytes and in the case of $\mathrm{ZH}$ the capacity Proliferative function of the chondrocytes is diminished by the differentiation process that these cells have undergone (van der Eerden et al.).

At the histological level in the samples submitted to underwater LIPUS a significant increase in the number of $\mathrm{CC}$ and of cells per column in the $\mathrm{ZH}$ was observed. When evaluating the effects of LIPUS on the temporomandibular joint of rats, Oyanarte et al. evidenced a significant increase in height and variations in the columnar organization of rodents stimulated with LIPUS for 26 days for 10 minutes daily. A similar result was obtained by El-Bialy et al. to observe an increase in the columnar organization of $\mathrm{ZH}$ in $\mathrm{CP}$ of temporomandibular joints of male rabbits, after the application of LIPUS for 4 weeks for 20 minutes a day.

These results are in contrast to those described by Abramovich et al. (1970) and Lyon et al.; Lyon showed a significant decrease in the organization of both $\mathrm{ZH}$ and ZP after application of high doses $\left(2.2 \mathrm{~W} / \mathrm{cm}^{2}\right)$ in tibia and femur of 6-week rabbits, with a 6-week application of 20 minutes daily. On the other hand, Abramovich when using samples of tibia and femur of female Wistar rats of 30 days observed a disorganization product of the application of US at higher intensities $\left(7 \mathrm{~W} / \mathrm{cm}^{2}\right)$ for 10 minutes. However, the high intensity used by Abramovich and Lyon is related to an increase in the temperature of the deep tissues, which could explain the observed effects (Abramovich et al.; Lyon et al.; Poliachik et al.). In the present study no similar results were observed possibly because this thermal effect has been diminished by the intensities of LIPUS $\left(30 \mathrm{~mW} / \mathrm{cm}^{2}\right)$ and the underwater application modality.

The results obtained in the present study could be explained by an increase in the cellular proliferation triggered by mechanoreceptors located mainly in the chondrocytes of the ZR and ZP (Nilsson et al., 2004, Takuchi et al., 2008, Padilla et $a l$.). The increase in proliferation generates a greater number of cells per unit area, causing an accumulation of cells that will differentiate and enter together in the $\mathrm{ZH}$, thereby increasing the number of cells per column and the increase of complete columns (Nilsson et al., 2004). 
Another possible mechanism is directly related to the mechanical waves generated by LIPUS, it has been described that these waves can organize the cellular distribution through extracellular fluid flows (Zauhar et al.), or through the direct interaction with the Proteins of the cell membrane, stimulating the organization between contiguous cells and between these cells and the MEC (Padilla et al.).

In relation to the contraindication of applying ultrasound on growth plates, it has been described that it is one of the most named in the literature (Batavia). And it relies mainly on studies that have shown that high doses of therapeutic ultrasound can produce PC closure (De Forest et al., 1953), where one of the mechanisms possibly implicated is the thermal effects of the US. In the case of the present study, the thermal effects were minimized by the underwater application methodology and the calibration of the equipment in relation to the distance of the fields. In this sense the main mechanisms that could account for the observed results would be mechanical effects on the tissues. In analyzing the results observed in the present study we realize that they do not necessarily tend to a PC closure as described in the contraindication, it is for this reason that we can argue that possibly the US has effects on the PC, but that these are differentiated according to the dosage, modality of application or even, to the predominance of thermal effects or mechanical effects on the fabric.

For future studies it is important to evaluate the effects of LIPUS on the production of local factors of the PC that could be controlling the growth of plaque.

Based on the results obtained in the present study it is possible to conclude that LIPUS in underwater modifies the histomorphometry of the proximal epiphyseal PC of the tibia of rodents in the late postnatal stage, promoting proliferation and columnar organization in the proliferative zone and hypertrophic, respectively. In relation to the contraindication of applying US on PC, the observed results support the theory that the US modifies the development of CP, but probably its effects are intensity dependent, where intensities similar to LIPUS in underwater mode would not produce a premature closure of The PC. More studies are needed in the area to elucidate the real effects of the US at different intensities and their possible utilities in bone tissue.

HENRÍQUEZ, R.; YUING, T.; PALLAUTA, G.; MUÑOZ, R.; SAAVEDRA, A.; NUÑEZ, P. \& VALENZUELA, M. Efectos del ultrasonido subacuatico sobre la morfohistología de la placa de crecimiento de ratones CF-1 en etapa de lactancia tardia. Int. J. Morphol., 35(4):1351-1358, 2017.
RESUMEN: El ultrasonido es una de las herramientas más utilizadas en fisioterapia, su modalidad LIPUS permite tratar lesiones músculo-esqueléticas, pero al igual que el ultrasonido convencional está contraindicada su aplicación en zonas próximas a cartílago de crecimiento por un posible cierre de éste. En la literatura no existe evidencia contundente de esta contraindicación, por lo cual el objetivo del presente estudio fue evaluar los efectos de dosis equivalentes a LIPUS subacuático sobre la histomorfometría de la placa de crecimiento de la epífisis proximal de tibia en un modelo animal. Metodología. Se aplicó LIPUS en modalidad subacuática en el miembro pélvico derecho a 8 ratones en $\mathrm{p} 15$ por 4 días, 2 veces al día. Al cumplir 8 sesiones se sacrificaron y se evaluó la histología de la placa de crecimiento del miembro estimulado. Al evaluar la histomorfometría de la placa se observó un aumento significativo en el espesor y el área de la zona proliferiva estimulada con LIPUS ( $\mathrm{p}=0.048$ ). En la zona hipertrófica no se observaron diferencias significativas en el espesor ni en las áreas, pero si existieron cambios significativos en la organización histológica de la zona, observando un aumento significativo de las columnas completas en la placa estimulada $(\mathrm{p}=0,04)$. El LIPUS en modalidad subacuática modifica la histomorfometría de la PC epifisiaria proximal de la tibia de roedores en el etapa postnatal tardía, promoviendo la proliferación y la organización columnar en la zona proliferativa e hipertrófica, respectivamente.

PALABRAS CLAVE: Ultrasonido pulsátil de baja intensidad; Ratón CF-1; Lactancia tardía; Placa de crecimiento.

\section{REFERENCES}

Abramovich, A. Effect of ultrasound on the tibia of the young rat. J. Dent. Res., 49(5):1182, 1970.

Barreto, A. A.; Barreto, R. K. A.; Pereira, H. da R. \& Hosnne, W. S. Effects of therapeutic ultrasound on longitudinal growth of the femur and tibia in rats. Acta Ortop. Bras., 19(3):132-6, 2011.

Batavia, M. Contraindications for superficial heat and therapeutic ultrasound: do sources agree? Arch. Phys. Med. Rehabil., 85(6):100612,2004

Bustamante, C.; Henríquez, R.; Medina, F.; Reinoso, C.; Vargas, R. \& Pascual, R. Maternal exercise during pregnancy ameliorates the postnatal neuronal impairments induced by prenatal restraint stress in mice. Int. J. Dev. Neurosci., 31(4):267-73, 2013.

Cameron, M. Agentes Físicos en Rehabilitación. $2^{\mathrm{a}}$ ed. Barcelona, Elsevier, 2009.

De Forest, R. E.; Herrick, J. F.; Janes, J. M. \& Krusen, F. H. Effects of ultrasound on growing bone; an experimental study. Arch. Phys. Med. Rehabil., 34(1):21-31, 1953.

El-Bialy, T.; El-Shamy, I. \& Graber, T. M. Growth modification of the rabbit mandible using therapeutic ultrasound: is it possible to enhance functional appliance results? Angle Orthod., 73(6):631-9, 2003.

Korstjens, C. M.; van der Rijt, R. H.; Albers, G. H.; Semeins, C. M. \& Klein-Nulend, J. Low-intensity pulsed ultrasound affects human articular chondrocytes in vitro. Med. Biol. Eng. Comput., 46(12):1263-70, 2008.

Lyon, R.; Liu, X. C. \& Meier, J. The effects of therapeutic vs. high-intensity ultrasound on the rabbit growth plate. J. Orthop. Res., 21(5):865-71, 2003.

Mackie, E. J.; Ahmed, Y. A.; Tatarczurch, L.; Chen, K. S. \& Mirams, M. Endochondral ossification: how cartilage is converted into bone in the 
HENRÍQUeZ, R.; YUING, T.; PALlAUTA, G.; MUÑOZ, R.; SAAVEDRA, A.; NUÑEZ, P. \& VALENZUELA, M. Effects of underwater lipus on the morphohistology of the CF-1 mice growth plate in late lactation stage. Int. J. Morphol., 35(4):1351-1358, 2017.

developing skeleton. Int. J. Biochem. Cell Biol., 40(1):46-62, 2008.

Miralles-Flores, C. \& Delgado-Baeza, E. Histomorphometric analysis of the epiphyseal growth plate in rats after prenatal alcohol exposure. $J$. Orthop. Res., 10(3):325-36, 1992.

Nolte, P. A.; Klein-Nulend, J.; Albers, G. H.; Marti, R. K.; Semeins, C. M.; Goei, S. W. \& Burger, E. H. Low-intensity ultrasound stimulates endochondral ossification in vitro. J. Orthop. Res., 19(2):301-7, 2001.

Olfert, E. D.; Cross, B. M. \& McWilliam, A. A. Guide to the care and use of experimental animals. 2a ed. Ottawa, Canadian Council on Animal Care, 1993.

Oyanarte, R.; Zárate, M. \& Rodriguez, F. Low-intensity pulsed ultrasound stimulation of condylar growth in rats. Angle Orthod., 79(5):964-70, 2009.

Padilla, F.; Puts, R.; Vico, L. \& Raum, K. Stimulation of bone repair with ultrasound: a review of the possible mechanic effects. Ultrasonics, 54(5):1125-45, 2014.

Poliachik, S. L.; Khokhlova, T. D.; Wang, Y. N.; Simon, J. C. \& Bailey, M. R. Pulsed focused ultrasound treatment of muscle mitigates paralysisinduced bone loss in the adjacent bone: a study in a mouse model. Ultrasound Med. Biol., 40(9):2113-24, 2014.

Shaw, A. \& Hodnett, M. Calibration and measurement issues for therapeutic ultrasound. Ultrasonics, 48(4):234-52, 2008.

Snow, M. E. \& Keiver, K. Prenatal ethanol exposure disrupts the histological stages of fetal bone development. Bone, 41(2):181-7, 2007.

Takeuchi, R.; Ryo, A.; Komitsu, N.; Mikuni-Takagaki, Y.; Fukui, A.; Takagi, Y.; Shiraishi, T.; Morishita, S.; Yamazaki, Y.; Kumagai, K.; Aoki, I. \& Saito, T. Low-intensity pulsed ultrasound activates the phosphatidylinositol 3 kinase/Akt pathway and stimulates the growth of chondrocytes in three-dimensional cultures: a basic science study. Arthritis Res. Ther, 10(4):R77, 2008

van der Eerden, B. C.; Karperien, M. \& Wit, J. M. Systemic and local regulation of the growth plate. Endocr. Rev., 24(6):782-801, 2003

Villemure, I. \& Stokes, I. A. Growth plate mechanics and mechanobiology. A survey of present understanding. J. Biomech., 42(12):1793-803, 2009.

Wiltink, A.; Nijweide, P. J.; Oosterbaan, W. A.; Hekkenberg, R. T. \& Helders, P. J. Effect of therapeutic ultrasound on endochondral ossification. Ultrasound Med. Biol., 21(1):121-7, 1995.

Zauhar, G.; Duck, F. A. \& Starritt, H. C. Comparison of the acoustic streaming in amniotic fluid and water in medical ultrasonic beams. Ultraschall. Med., 27(2):152-8, 2006.

Zhang, Z. J.; Huckle, J.; Francomano, C. A. \& Spencer, R. G. The effects of pulsed low-intensity ultrasound on chondrocyte viability, proliferation, gene expression and matrix production. Ultrasound Med. Biol., 29(11):1645-51, 2003.

\author{
Corresponding author: \\ Ricardo Henríquez F. \\ Escuela de Kinesiología \\ Universidad Santo Tomas \\ Sede Viña del Mar \\ Viña del Mar \\ CHILE
}

Email: ricardohenriquezfl@santotomas.cl

Received: 29-05-2017

Accepted: 14-07-2017 